\title{
Social Capital and Knowledge Sharing as Determinants of Academic Performance
}

\author{
M.M. Haris Aslam \\ Khuram Shahzad \\ Aly Raza Syed \\ Asher Ramish \\ University of Management \& Technology \\ Author's Notes
}

Correspondence regarding this article should be addressed to M.M. Haris Aslam, Department of Operations and Supply Chain, University of Management and Technology, C II, Johar Town, Lahore, Pakistan. Contact: haris.aslam@umt.edu.pk

\begin{abstract}
Many researchers argue that career success of various individuals can be attributed to the effective use of social capital. Social capital theory proposes that the network of relationships support the people in performing social affairs and advancing in their careers. A considerable body of knowledge exists that examines the role social capital plays in the success of individuals and organizations. However, not many have focused on the social capital development process in the higher education institutions. This understanding is vital because higher educational institutions are the breeding grounds of the behaviors that help the students to excel in their professional lives. Current study empirically examines the relationship between social capital and knowledge sharing, and how knowledge sharing impacts academic performance. For this purpose multiple linear regression analysis has been performed. The results of the analysis highlight various aspects of the relationship between social capital, knowledge sharing and academic performance. Understanding how students learn to share knowledge in their respective social networks and the motivation behind this knowledge sharing, can help the university authorities in identifying the steps that can facilitate the process of knowledge sharing which in turn can lead to enhancement in the quality of the learning process.
\end{abstract}

Keywords: Social Capital, Knowledge Sharing, Academic Performance, Higher Education 


\section{Introduction}

People progress in their careers on various trajectories. Some progress faster than the others. This performance difference has been explained using various types of reasoning. "Human capital" approach for example, suggests that these differences exist because of the differences in the abilities of individuals. However, it has been argued that human capital of a person is useless without "social capital" (Burt, 1997). Social capital is "the goodwill that is engendered by the fabric of social relations and that can be mobilized to facilitate action" (Adler $\&$ Kwon, 2002). The central theme of social capital theory is that network of relationships support the people in performing social affairs. Hence providing them with a jointly owned "capital" rooted within the networks of shared acquaintances (Nahapiet \& Ghoshal, 1998). Just like other forms of capital, social capital is a productive resource that supports both individual and organizational actions (Tsai \& Ghoshal, 1998). Adler \& Kwon (2002) suggested that mutual goodwill amongst people (their social capital) is a valuable resource and this goodwill is composed of sympathy, trust and forgiveness. Tsai \& Ghoshal (1998) suggested that social capital encapsulates social interactions such as relationships, trust, and norms that support actions in a particular setting. Various conceptual and empirical studies have discussed how social capital relates to as diverse variables as the following;

- $\quad$ Intellectual capital formation (Nahapiet \& Ghoshal, 1998)

- $\quad$ Knowledge creation (Krause, et al., 2007) and sharing (Chow \& Chan, 2008; Monnavarian \& Amini, 2009; Wasko \& Faraj, 2005; Weber \& Weber, 2007)

- Various indicators of organizational performance (Bolino, et al., 2002; Krause, et al., 2007; Yang, et al., 2011)

- $\quad$ Competitive advantage (Bolino, et al., 2002; Nahapiet \& Ghoshal, 1998; Yli-

Renko, et al., 2001)

- $\quad$ Better team performance (Rosenthal, 1997)

- $\quad$ Democracy and development (Evans, 1996; Hyden, 1997; Woolcock, 1998) and

better performance of political institutions (Boix \& Posner, 1996)

- $\quad$ Customer loyalty (Jones \& Taylor, 2012)

- $\quad$ Better hiring performance (Fernandez, et al., 2000)

- $\quad$ Attainment of better status (Lin, 1999)

- $\quad$ Reduction in stress (Savage \& Torgler, 2010)

- $\quad$ Reduction in transaction costs (McCallum \& O'Connell, 2009)

- $\quad$ Citizenship behavior (Bolino, et al., 2002)

Value that managers add to their organizations in part is based on their skills of communicating with other people, adding value for the organization by gathering right people that can develop opportunities. Knowledge of how these tasks can be performed is the result of a managers' network that extends beyond the organization (Burt, 1997). Savage \& Torgler (2010) pointed out that most commonly mentioned benefits of social capital are usually tangible resources e.g. gaining access to capital or individuals with resources. However gaining social support is an equally important benefit. Other benefits include information availability, influence, control, power, and solidarity (Adler \& Kwon, 2002).

Importance of knowledge sharing in modern organization cannot be over emphasized. There is an agreement amongst the researchers that knowledge as an asset is related to success (Tohidinia \& Mosakhani, 2010). Knowledge requires nurturing and support. Developing a thought process that focuses on behavior of individuals in the social network regarding 
knowledge sharing can lead to the formation of plat-form and development of norms of knowledge sharing (Widén-Wulff \& Ginman, 2004). Joint creation of knowledge by individuals and organizations can lead to synergistic growth in knowledge (Nonaka, 1994). A considerable body of knowledge has accumulated during the recent times that discusses the antecedents and outcomes of knowledge sharing (see Bock, et al., 2005; Hansen, 1999, 2002; Levin \& Cross, 2004; Mu, et al., 2008; Teng \& Song, 2011; Tohidinia \& Mosakhani, 2010; Yli-Renko, et al., 2001).

Social capital can be conceptualized at many different levels such as individuals, organizations, inter-organizational arrangements and societies (Tsai \& Ghoshal, 1998). A considerable body of knowledge exists that discusses the role social capital plays in the success of individuals and organizations. However, not many have focused on the social capital development process in the higher education institutions. Tymon \& Stumpf (2003) predicted that success in the $21^{\text {st }}$ century will not be based merely upon knowledge and technical skills but upon the ability to learn and share quickly with the network of relationships. Success in social systems is contingent upon development and growth of relationships. Developing an understanding of how and why individuals decide about sharing their knowledge is important (Chiu, et al., 2006). Understanding how students learn to share their knowledge in their networks and the motivation behind it can lead to steps taken by the university authorities that can facilitate the process of knowledge sharing by providing the student platforms (structural help). These mechanisms can then be replicated in their professional lives in order to attain competitive advantage.

Current study is organized in the following manner. Section 2 presents a brief literature review on social capital and knowledge sharing. In section 3 hypotheses to be tested in the study have been formulated. Section 4 discusses the research methods. Section 5 presents the results of the data analysis. Section 6 provides the discussion of the results and implications of the study.

\section{Literature Review}

\section{Social Capital Theory}

Nahapiet \& Ghoshal (1998) defined social capital as "the sum of the actual and potential resources embedded within, available through, and derived from the network of relationships possessed by an individual or social unit". Adler \& Kwon (2002) stated that social capital is a durable asset in which resources are invested so that they may return the benefits in future. It is an advantage that exists because of location of an individual or a group in the social structure (Widén-Wulff \& Ginman, 2004). Social capital is not necessarily context specific i.e. network formed in one context may be transformed to another (Adler \& Kwon, 2002; Jones \& Taylor, 2012; Nahapiet \& Ghoshal, 1998). For example the network formed in academic environment of a university can be used by the students later in their professional lives.

Social capital is similar to the other forms of capital in that it; is productive, leads to achievement of certain objectives which otherwise would not be achievable (Coleman, 1988), can substitute or complement other resources, and requires "upkeep" (Adler \& Kwon, 2002). It differs however from the other forms of capital in that it cannot be traded easily (Nahapiet \& Ghoshal, 1998) as it is not residing in a social member (person or an organization) but a network of members (Coleman, 1988). It is not the exclusive property of any one member in a social 
network, rather it is jointly owned by the whole network (Nahapiet \& Ghoshal, 1998). It can be accumulated just like knowledge or other types of capital (Tymon \& Stumpf, 2003).

Social capital provides benefits related to information (Burt, 1997; Nahapiet \& Ghoshal, 1998) such as; access to information which is outside ones grasp alone, timing: availability of the information at the time when it is most useful, and referrals that a person receives from ones network that present a person in a positive way in the right places; and control benefits that result from ones central position in the network and lead towards control over whose interests get the priority (Burt, 1997). Managers with a higher social capital know about and are able to control lucrative opportunities. They are able to gather and direct information where it is required with higher level of effectiveness (Burt, 1997). Through social capital efficiency of the action that a person takes is increased (Nahapiet \& Ghoshal, 1998). The structure of interactions in a social network affects the shaping of a common vision. These interactions not only lead to the adoption of the organizations' vision, language, norms and practices but also to the formation of new ones (Tsai \& Ghoshal, 1998). More social capital is also associated with early promotions and higher bonuses (Burt, 1997).

Nahapiet and Ghoshal (1998) suggested that social capital is a construct consisting of structural, relational, and the cognitive dimensions. These dimensions will be discussed in the following sections. 
Structural Dimension. Structure is important for the formation and utilization of social capital (Widén-Wulff \& Ginman, 2004). Structural dimension refers to the pattern of connections between the members of the network. Important aspects of this dimension are ties between the members of a social network; network structure based on density, connectivity and hierarchy; and multipurpose use of networks (Nahapiet \& Ghoshal, 1998). Bolino, et al. (2002) propsed: structural holes (absence of connection between network members), concentration (amount of connections concentrated amongst few network members), and density (potential versus existing connections amongst the network members) as the indicators of structural dimension. Interactions between the organization members by physical or electronic means such as meetings, teamwork, emails or online discussion forums facilitate the access to knowledge amongst various members. As a result, the overall knowledge creation increases (Chua, 2002). The location of a member's contacts in the social relationships is also a source of certain advantages. These contacts can be used to gain information, resources and jobs (Tsai \& Ghoshal, 1998). Nahapiet and Ghoshal (1998) suggested that structural dimension of social capital is associated with the knowledge sharing and associated activities. Current study employs social interaction ties as the indicator of structural dimension of social capital.

Relational Dimension. Relational dimension of social capital consists of assets which are created through, and can be benefited from, by relationships. It is based on relationships that the people have which can affect their behavior e.g. respect and friendship. These relationships are the source of fulfillment of social needs such as sociability, approval and prestige (Nahapiet \& Ghoshal, 1998) and lead to the development of trust and identification with one another (Bolino, et al., 2002). It also describes the degree of trust ensuing from social interaction (Chow \& Chan, 2008). Along with the network of relationships, trust and norms are important sources of social capital (Adler \& Kwon, 2002). Thus the key aspects of this dimension are trust, norms, obligations and expectations and identification (Chow \& Chan, 2008; Nahapiet \& Ghoshal, 1998).

Cognitive Dimension. Cognitive dimension relates to the resources that allow the formation of shared interpretations and meanings within a network or organization (Chow \& Chan, 2008; Wasko \& Faraj, 2005). This dimension of social capital is embedded in the properties such as common language or vision that support a common understanding of shared goals and norms of action in a social setting. Within large, complex organizations, shared vision and values facilitate the development of cognitive dimension of social capital that by supporting individual and joint actions, benefit organization (Tsai \& Ghoshal, 1998). Cognitive social capital of individuals is the outcome of frequent interactions while sharing the same practices, which lead the individuals to learn skills, knowledge and common conventions (Wasko \& Faraj, 2005). Current study uses shared language and shared vision as indicators of cognitive dimension of social capital.

\section{Knowledge Sharing}

Recent years have seen more emphasis being laid on intellectual rather than physical assets. The workers of the modern economy have become "knowledge workers". Researchers have divided knowledge into two types: explicit and tacit knowledge. Explicit (or codified) knowledge exists in the forms that can be transmitted through formal means such as language. Tacit knowledge on the other hand resides in people and cannot be readily transmitted through formal communication. Most of the knowledge exists in the tacit form. Benefits from tacit 
knowledge can only be achieved if knowledge is shared through socialization process (Nonaka, 1994). Knowledge sharing is thus an important issue in modern organizations (Teng \& Song, 2011). Creating communities that share knowledge is a social challenge (Widén-Wulff \& Ginman, 2004). Since knowledge is a source of competitive advantage, high level of motivation would be required for an individual to share his or her knowledge. It requires a platform, culture and certain amount of trust between individuals of a collective to induce them to share their knowledge.

\section{Social Capital and Knowledge Sharing}

Not all individuals or organizations possess the complete knowledge that can lead to success. Hence reliance upon external sources of knowledge is evident. A great part of knowledge exists in social interactions (Lang, 2004). According to Mu, et al.(2008) knowledge creation and sharing are processes that cannot be induced through coercion; rather they are social processes facilitated by social capital. External networking allows individuals to gain knowledge which is otherwise not available. Similarly external networks allow the individuals in the organizations to gain knowledge (information, expertise and ideas) beyond the bounds of the hierarchies and local rules (Wasko \& Faraj, 2005). Nahapiet and Ghoshal (1998) argued that social capital affects the conditions requisite for the knowledge creation and sharing favorably. Norm of cooperation in a social network also facilitates knowledge sharing.

Current study views social capital as an antecedent of knowledge sharing. It hypothesises a positive relationship between social capital and knowledge sharing. The following section presents the hypotheses to be tested in the current study.

\section{Social Interaction Ties}

\section{Hypotheses Formulation}

Social relationships act as channels providing access to information which would otherwise require significant investment (Coleman, 1988). Social interaction ties are the connections between network members (Bolino, et al., 2002). They act as a medium for information flow and resource exchanges. They provide the members of the network access to the resources of other members. Further these interactions shape the common goals and norms and lead to the sharing of these goals and norms throughout the network (Tsai \& Ghoshal, 1998). Chua (2002) argued that social interaction enhances the quality of knowledge created in an organization. Knowledge sharing process is likely to be higher when members of a network know each other well (Bolino, et al., 2002) and interact frequently. Decision regarding trusting a person and sharing knowledge is contingent upon knowing the individual. This knowledge is supported through the network of relations (Mu, et al., 2008). Tsai and Ghoshal (1998) found a significant relationship between social interaction ties and resource exchange. Chiu et al.(2006) operationalized social interaction ties as consisting of the relationship, time spent, frequency of interaction between the members of academic social network. Their empirical investigation showed that social interaction ties are related to the knowledge sharing. Mu et al. (2008) based on their qualitative findings also argued that strong interaction ties facilitate knowledge sharing. Hence,

H1: Social interaction ties between the members of a social network will impact knowledge sharing by its members positively. 


\section{Trust}

Amongst the various organizational coordination mechanisms, trust is achieving ever increasing importance in modern knowledge economy. Relative to trust, price and authority are not very effective while dealing with knowledge based assets (Adler, 2001). Trust is an enabler for social exchange and cooperation and it opens up people for knowledge sharing. It facilitates cooperation which in turn begets trust (Nahapiet \& Ghoshal, 1998). Members of a social network who trust each other are more willing to share their resources since they have no fear of being exploited by the other members. Hence cooperation that leads to resource sharing predicates trust. Network members may share information about the trustworthiness of other members. The trustworthiness of network members thus makes them more likely companion in information exchange (Tsai \& Ghoshal, 1998). Another aspect of trust is integrity which relates to the expectation that members in network will follow a generally accepted code of conduct (Chiu, et al., 2006). Tsai and Ghoshal (1998) showed that trust is positively related to resource exchange where as Chiu et al. (2006) showed that trust is significantly related to the knowledge sharing. Similar results were also found in Nelson \& Cooprider (1996) and Mu, et al. (2008).

H2: Trust between the members of a social network will impact knowledge sharing by its members positively.

\section{Norm of Reciprocity}

"Norm of reciprocity refers to knowledge exchanges that are mutual and perceived by the parties as fair" (Chiu, et al., 2006). In this respect social capital can be conceptualized as being very similar to "money capital" (Portes \& Sensenbrenner, 1993). Coleman (1988) argued that if a person does a favor and trusts that the other person will reciprocate then this becomes an expectation for the first while an obligation for the second. If many members of a social network owe favor to the first, then this bears great resemblance to the financial capital. So a person who has higher numbers of obligations outstanding from others towards him or her has more social capital to benefit from. It is expected that knowledge sharing in an academic social network by a member is induced by the expectation that others would reciprocate the act when required. Tohidinia \& Mosakhani (2010) showed that norm of reciprocity was positively related to knowledge sharing.

H3: Norm of reciprocity in a social network will impact knowledge sharing by its members positively.

\section{Identification}

Through identification process people perceive themselves as associated with a person or a group. It acts as a resource that affects the perception of benefit from knowledge exchange (Nahapiet \& Ghoshal, 1998). It includes a members' sense of belongingness and positive feelings towards a social network and explains the readiness to remain an active member of the network. Individuals usually tend not to share knowledge until other people are recognized as "group-mates". Hence identification with the community is important in stimulating knowledge sharing behaviors (Chiu, et al., 2006). Identifying with a group or community also fills in the human need for belongingness. It is therefore expected that members of an academic social 
network would share their knowledge as a result of/ in expectation of being or remaining a part of the network. Chiu et al. (2006) in their study found a positive relationship between indentification and knowledge sharing. Therefore,

H4: Identification with a social network will impact knowledge sharing by its members positively.

\section{Shared Language}

Nahapiet and Ghoshal (1998) suggest that language plays a major role in the context of social relations insofar as it acts as an enabler of knowledge exchange. Further shared language is a tool for evaluation of benefits of knowledge exchange. In order for effective knowledge exchange to occur parties should have some common knowledge or shared vocabulary. Shared language is important to academic networks. It helps participants in developing better understanding of each other. Shared language not only facilitates knowledge sharing but also the communication efficiency. Further shared language motivates the network members to indulge in knowledge exchange activities actively and enhances the quality of knowledge shared in the network (Chiu, et al., 2006). It is therefore expected that shared language will be a major antecedent of knowledge sharing in an academic social network. Chiu et al. (2006) found a positive relationship between shared language and knowledge sharing.

H5: Shared language in a social network will impact knowledge sharing by its members positively.

\section{Shared Vision}

Shared vision consists of common goals and ambitions of the members of a social network. Common understanding about the ways of interaction leads to more and better opportunities for resource sharing without any misunderstanding. The common goals help the network members in visualizing the benefits of these exchanges. Hence the shared vision amongst the network members, leads to sharing of resources (Tsai \& Ghoshal, 1998). Since knowledge is a resource as well as a source of power, it is unnatural for people to share knowledge (Davenport, 1997). Norms of collectivity that guide an individual to leave individual interests for the community are a binding force for that community (Coleman, 1988). Shared goals, interests, visions in a community facilitate them in understanding the meaning of knowledge sharing (Chiu, et al., 2006). Common goals and norms lead to trust amongst the members of a network as they do not fear pursuit of self interest by any member of the network while compromising the common goals. Hence common goals and norms are a binding force that creates trust (Tsai \& Ghoshal, 1998) and can lead to knowledge sharing. Chiu et al. (2006) in their empirical study found that shared vision was positively related to the quality of knowledge shared on the network.

H6: Shared vision in a social network will impact knowledge sharing by its members positively.

\section{Knowledge Sharing and Academic Performance}

Organizational capabilities that lead to effective knowledge creation and transfer are an essential component of organizations' competitive advantage. Gathering and sharing of knowledge are complex social processes and most of the important knowledge is socially rooted 
in particular context, joint activities and relationships (Nahapiet \& Ghoshal, 1998). Quantity and channels of knowledge sharing is thus context specific. However in order to encourage investments (both time and money) in knowledge sharing activities, it is important to find its relationship with the performance. Relationship between knowledge sharing and performance has been explored in various contexts. Tsai and Ghoshal (1998) using a business unit as the unit of analysis showed that resource exchange and combination is related to value creation. Rhodes et al. (2008) found a significant relationship between knowledge sharing and financial performance of the organization. Hansen (2002) found that efficiency in knowledge sharing resulting from shorter network paths is related to the early completion of projects as compared to the divisions with a longer network path. Yli-Renko et al. (2001) found that knowledge acquisition is positively related to the new product development and the technological distinctiveness and negatively related to the sales costs. Current study explores the effect of knowledge sharing in an academic setting. However based on the above evidence it can be hypothesized that knowledge sharing would have a similar impact in academic setting as well. H7: Knowledge sharing in a social network will impact academic performance of its members positively. Hypothesized model for the study is shown in figure 1. In the next section we present the research methods employed in the study.

\section{Structural Dimension}

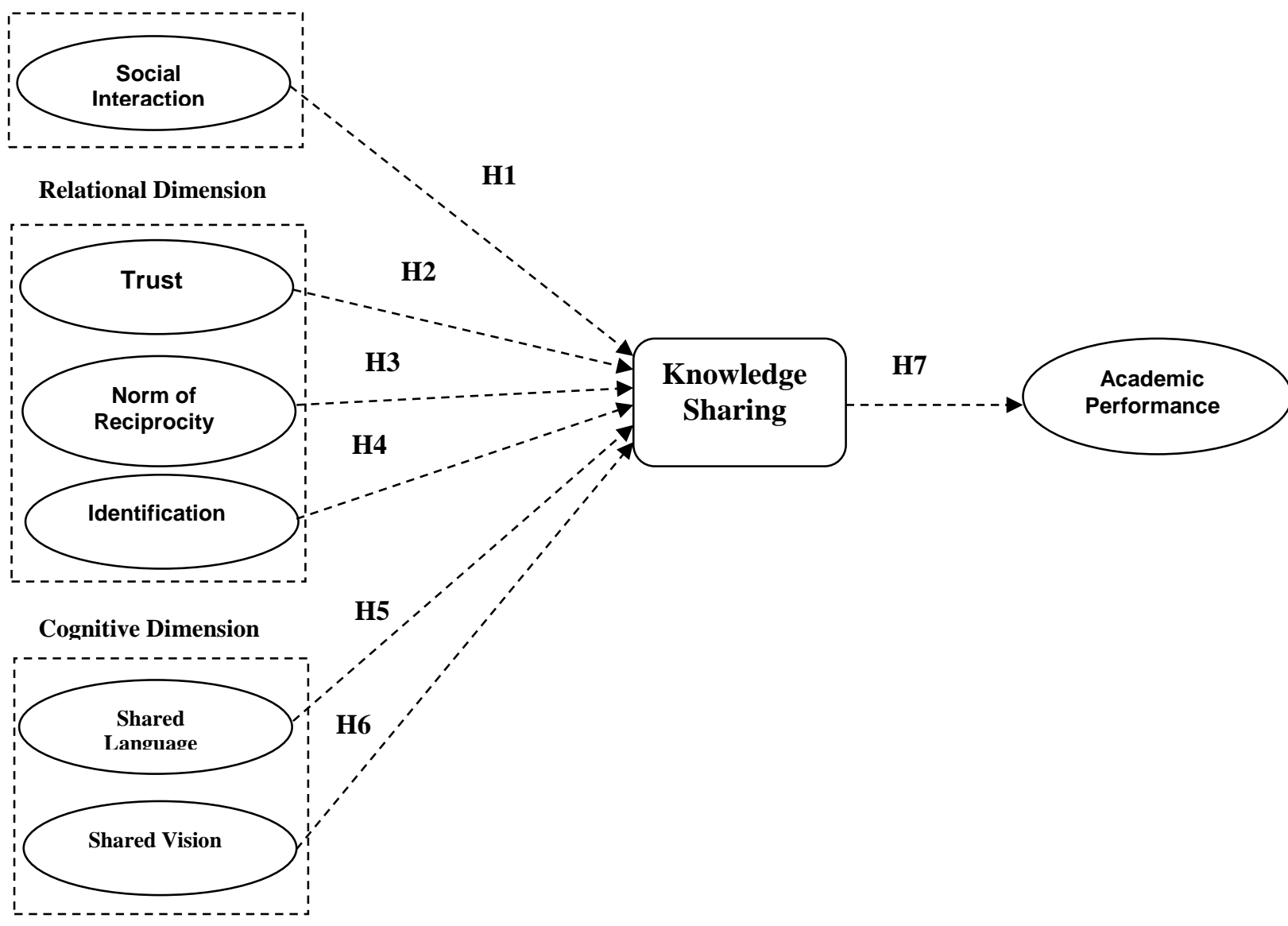

Figure 1. Hypothesized Model 


\section{Methods}

In order to test the hypothesized model empirically, survey methodology was employed in the current study. Following sections provide the details about validation of the survey instrument and the data collection.

\section{Survey Instrument}

The independent variables in the current study are related to the various dimensions of social capital while the dependent variables are knowledge sharing and academic performance. Survey items for the 6 scales related to the 3 dimensions of social capital and the items related to knowledge sharing were adapted from Chiu et al. (2006). Items were modified to fit the respondents of the current study. In order to do that the name of the community in Chiu et al. (2006) was replaced by "my academic social network" in all the items. All the responses were measured on the scale of $1=$ strongly disagree to $7=$ strongly agree. Cumulative Grade Point Average (CGPA) of the participants was used as an indicator of academic performance. In the next step construct validation process was undertaken.

\section{Content Validity}

Content validity (or face validity) accesses whether the items in the scale are comprehensive and representative of the constructs (Monnavarian \& Amini, 2009). The survey items in the current study were identified after an extensive review of the literature. This survey instrument was validated by Chiu et al. (2006) in their study. Further, expert judgments were used to refine the survey instrument however no changes were suggested to the instrument in this phase.

\begin{tabular}{|c|c|c|c|c|c|c|c|c|}
\hline \multicolumn{9}{|c|}{$\begin{array}{l}\text { Table } 1 \\
\text { Correlation Matrix }\end{array}$} \\
\hline & $T$ & $N R$ & $I D$ & $S L$ & $S V$ & $P O E$ & COE & $K S$ \\
\hline SIT & $.266^{* *}$ & $.217^{*}$ & $.530^{* *}$ & $.577^{* * *}$ & $.329^{* * *}$ & $.497^{* * *}$ & $.416^{* * *}$ & $.260^{\text {*** }}$ \\
\hline $\mathrm{T}$ & & $.519^{* * *}$ & $.379^{* *}$ & $.256^{* * *}$ & $.478^{* * *}$ & $.219^{*}$ & $.298^{* * *}$ & $.384^{* * *}$ \\
\hline NR & & & $.462^{* *}$ & .162 & $.449^{* *}$ & $.227^{*}$ & $.241^{*}$ & $.327^{* * *}$ \\
\hline ID & & & & $.515^{* * *}$ & $.451^{* *}$ & $.532^{* *}$ & $.608^{* * *}$ & $.348^{\text {*** }}$ \\
\hline SL & & & & & $.429^{* * *}$ & $.668^{* * *}$ & $.587^{* *}$ & $.381^{\text {*** }}$ \\
\hline SV & & & & & & $.466^{* *}$ & $.520^{* * *}$ & $.476^{\text {*** }}$ \\
\hline POE & & & & & & & $.651^{* * *}$ & $.317^{* * *}$ \\
\hline $\mathrm{COE}$ & & & & & & & & $.441^{* * *}$ \\
\hline
\end{tabular}




\section{Criterion-Related Validity}

Criterion related validity (or predictive validity) exists when constructs in the measurement instrument are related to an independent measure of a related criterion (Das, et al., 2008). In the current study criterion validity was degree to which social capital constructs were related to knowledge sharing measures. In order to assess the relationship bi-variate correlations were computed. The results are shown in table 1 . The table shows that all the constructs of social capital are significantly related to knowledge sharing $(\mathrm{p}$-value $<0.01)$.

Table 2

Summary of Measurement Scales

\begin{tabular}{|c|c|c|c|c|}
\hline & $\begin{array}{l}\text { Factor } \\
\text { Loadings }\end{array}$ & Cronbach $\alpha$ & Mean & $\begin{array}{l}\text { Standard } \\
\text { Deviation }\end{array}$ \\
\hline Social interaction ties (SIT) & & 0.83 & 5.28 & 1.14 \\
\hline $\begin{array}{l}\text { I maintain close social relationships with some members } \\
\text { in my academic social network. }\end{array}$ & .765 & & & \\
\hline $\begin{array}{l}\text { I spend a lot of time interacting with some members in my } \\
\text { academic social network. }\end{array}$ & .790 & & & \\
\hline $\begin{array}{l}\text { I know some members in my academic social network on } \\
\text { a personal level. }\end{array}$ & .625 & & & \\
\hline $\begin{array}{l}\text { I have frequent communication with some members in my } \\
\text { academic social network. }\end{array}$ & 671 & & & \\
\hline Trust (TR) & & 0.84 & 4.35 & 1.21 \\
\hline $\begin{array}{l}\text { Members in my academic social network will not take } \\
\text { advantage of others even when the opportunity arises. }\end{array}$ & .738 & & & \\
\hline $\begin{array}{l}\text { Members in my academic social network will always keep } \\
\text { the promises they make to one another. }\end{array}$ & .863 & & & \\
\hline $\begin{array}{l}\text { Members in my academic social network would not } \\
\text { knowingly do anything to disrupt the conversation. }\end{array}$ & .789 & & & \\
\hline $\begin{array}{l}\text { Members in my academic social network behave in a } \\
\text { consistent manner. }\end{array}$ & 672 & & & \\
\hline $\begin{array}{l}\text { Members in my academic social network are truthful in } \\
\text { dealing with one another. }\end{array}$ & .635 & & & \\
\hline Norm of reciprocity (NR) & & 0.74 & 5.00 & 1.19 \\
\hline $\begin{array}{l}\text { I know that other members in my academic social network } \\
\text { will help me, so it's only fair to help other members. }\end{array}$ & .611 & & & \\
\hline $\begin{array}{l}\text { I believe that members in my academic social network } \\
\text { would help me if I need it. }\end{array}$ & .609 & & & \\
\hline Identification (ID) & & 0.76 & 5.23 & 0.91 \\
\hline $\begin{array}{l}\text { I feel a sense of belonging towards my academic social } \\
\text { network. }\end{array}$ & .442 & & & \\
\hline $\begin{array}{l}\text { I have the feeling of togetherness or closeness in my } \\
\text { academic social network. }\end{array}$ & .620 & & & \\
\hline $\begin{array}{l}\text { I have a strong positive feeling toward my academic social } \\
\text { network. }\end{array}$ & .637 & & & \\
\hline $\begin{array}{l}\text { I am proud to be a member of my academic social } \\
\text { network. }\end{array}$ & .812 & & & \\
\hline Shared language (SL) & & 0.81 & 5.39 & 1.14 \\
\hline $\begin{array}{l}\text { The members in my academic social network use } \\
\text { common terms or jargons. }\end{array}$ & .731 & & & \\
\hline $\begin{array}{l}\text { Members in my academic social network } \\
\text { understandable communication pattern during } \\
\text { discussion. }\end{array}$ & .784 & & & \\
\hline $\begin{array}{l}\text { Members in my academic social network use } \\
\text { understandable narrative forms e.g. text messages, } \\
\text { emails etc. }\end{array}$ & .513 & & & \\
\hline Shared vision (SV) & & 0.81 & 4.70 & 1.13 \\
\hline $\begin{array}{l}\text { Members in my academic social network share the vision } \\
\text { of helping others solve their professional problems. }\end{array}$ & .770 & & & \\
\hline Members in my academic social network share the same & .688 & & & \\
\hline
\end{tabular}




\begin{tabular}{|c|c|c|c|c|}
\hline goal of learning from each other. & & & & \\
\hline $\begin{array}{l}\text { Members in my academic social network share the same } \\
\text { value that helping others is pleasant. }\end{array}$ & .694 & & & \\
\hline Knowledge sharing (KS) & & 0.79 & 4.79 & 1.07 \\
\hline $\begin{array}{l}\text { The knowledge shared by members my academic social } \\
\text { network is accurate. }\end{array}$ & .729 & & & \\
\hline $\begin{array}{l}\text { The knowledge shared by members in my academic } \\
\text { social network is complete. }\end{array}$ & .770 & & & \\
\hline $\begin{array}{l}\text { The knowledge shared by members in my academic } \\
\text { social network is reliable. }\end{array}$ & .719 & & & \\
\hline $\begin{array}{l}\text { The knowledge shared by members in my academic } \\
\text { social network is timely. }\end{array}$ & .593 & & & \\
\hline
\end{tabular}

\section{Construct Validity}

Construct validity measures the suitability of items to measure a latent variable (Forza \& Filippini, 1998). Exploratory factor analysis (EFA) is applied to identify which subsets of the variables are related to each other but are different from other variables (Tabachnick, et al., 2007). Principal component analysis was used to perform EFA in the current study. Varimax rotation was used for the ease of interpretation. The Bartlett test of sphericity (significance value $<0.05)$ and the Kaiser-Meyer-Olkin measure of sampling adequacy $(>0.70)$ were used to gauge the suitability of factor analysis. The result of factor analysis has been provided in table 2 . Here all the items loading on the construct of interest (loading > 0.4) were retained and others were dropped. Only 2 items from knowledge sharing construct were dropped in this process.

\begin{tabular}{|l|c|}
\hline \multicolumn{2}{|l|}{ Table 3} \\
\hline Sample Demographics \\
\hline Gender: & \\
\hline Male & 61 \\
\hline Female & 43 \\
\hline Average Age (Years) & 23.70 \\
\hline Nature of Education: & \\
\hline Business & 71 \\
\hline Non Business & 28 \\
\hline Education: & \\
\hline Undergraduate & 49 \\
\hline Graduate & 14 \\
\hline Post Graduate & 1 \\
\hline Other & 35 \\
\hline
\end{tabular}

\section{Internal Consistency Reliability}

A scale is reliable if it is not affected by random error (Forza \& Filippini, 1998). Cronbach's alpha (Cronbach, 1951) is a widely used measure of reliability. A value of Cronbach's alpha higher than 0.7 is usually considered appropriate (Hair Jr, et al., 2007). Cronbach's alpha's for the final scales after the factor analysis have been provided in table 2 . 
Survey instrument demonstrated high reliability since alpha values for all the scales are higher than 0.7 .

\section{Sample and Data Collection}

Data for the study were collected from students of various universities in Lahore.

Sampling was done on the convenience basis. Participants of the survey were informed about the purpose of the study. In all 148 participants took part in the study. After initial screening, 105 surveys were selected for the final study. Sample demographics have been provided in table 4.3. Summary measures for the data are shown in table 3.

\section{Results}

In order to test the hypothesized model, regression analysis was employed. Two models were tested; first one tested the impact of social capital dimensions on knowledge sharing while the second tested the impact of knowledge sharing on CGPA. The hypothesized models take the following form;

$\mathrm{KS}=\alpha+\mathrm{SIT}+\mathrm{T}+\mathrm{NR}+\mathrm{ID}+\mathrm{SV}+\mathrm{SL}+\varepsilon$

\section{$\mathrm{CGPA}=\alpha+\mathrm{KS}+\varepsilon$}

Results of the regression analysis are shown in tables 5.1 and 5.2. Table 5.1 shows that trust, shared vision and shared language significantly affect the knowledge sharing (p-value < 0.05). All the signs are in expected direction. Overall model is also significant (p-value $<0.01$ ) with adjusted R squared of 0.29 . Hence the support was found for H2, H5 and H6 while H1, H3 and $\mathrm{H} 4$ were not supported. Table 5.2 shows the results regarding the second model. Even though knowledge sharing is significant (p-value $<0.10 \& \mathrm{R}$ squared 0.035 ) in explaining the academic performance of the student in terms of CGPA, the sign is not in the expected direction i.e. the results show that higher level of knowledge sharing is negatively related to academic performance. Hence support could not be found for H7.

\begin{tabular}{|l|c|c|c|c|c|}
\hline Table 4 \\
Multiple Regression Output \\
\hline \multirow{4}{*}{ Model } & $\begin{array}{c}\text { Unstandardized } \\
\text { Coefficients }\end{array}$ & $\begin{array}{c}\text { Standardized } \\
\text { Coefficients }\end{array}$ & \multirow{2}{*}{$t$} & \multirow{2}{*}{ Sig. } \\
\cline { 2 - 5 } & B & $\begin{array}{c}\text { Std. } \\
\text { Error }\end{array}$ & Beta & & \\
\hline Constant & 1.586 & .503 & & 3.153 & .002 \\
\hline Trust & .168 & .084 & .189 & 1.995 & .049 \\
\hline Shared Vision & .302 & .096 & .317 & 3.128 & .002 \\
\hline Shared Language & .193 & .087 & .204 & 2.225 & .028 \\
\hline Dependent Variable: Knowledge Sharing & & \\
\hline
\end{tabular}




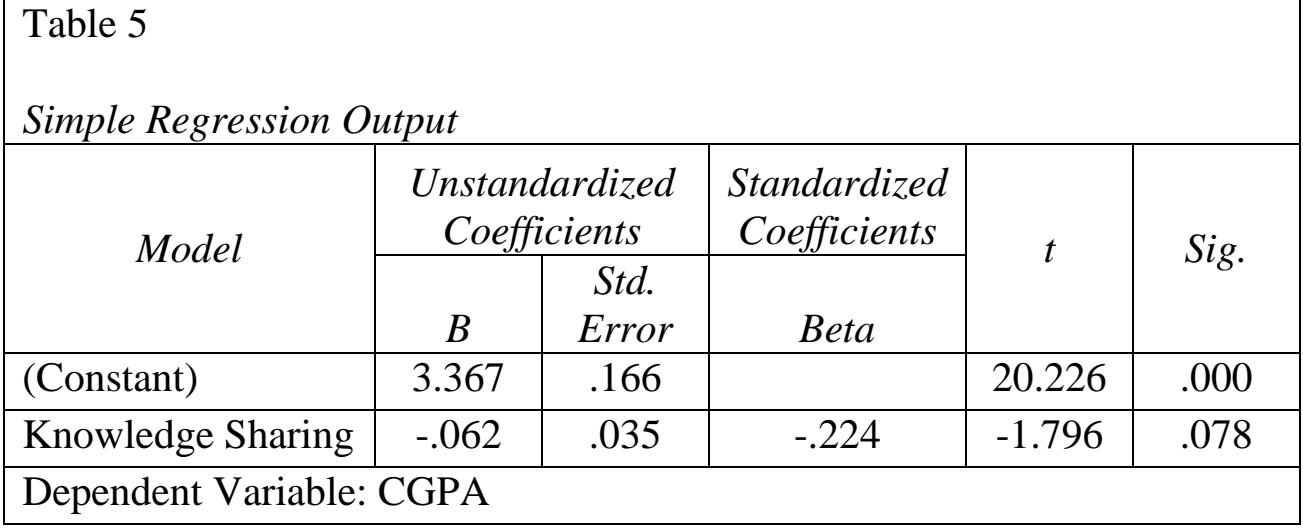

\section{Discussion and Implications}

Current study was conducted to develop an understanding about the relationship between social capital and knowledge sharing in an academic environment. Further it was explored how knowledge sharing relates to the academic performance of the students. The results of the study show a partial support for the argument that social capital leads to knowledge sharing. However not all dimensions of social capital are related to knowledge sharing. Analysis revealed that structural dimension does not impact knowledge sharing. These results are different from Wasko \& Faraj (2005) and Tsai \& Ghoshal (1998) who found a significant relationship between structural dimension and resource/knowledge sharing. Wasko \& Faraj (2005) conducted their study in an online setting. The importance of structural dimension is apparent in such an environment. Tsai \& Ghoshal's study was conducted in an organization using business unit as the unit of analysis. Hence the differences in the results of these studies could be attributed to differences in the research setting. Amongst the various indicators of relational dimension only trust was found to impact knowledge sharing. This corroborates the findings of Tsai \& Ghoshal (1998) who also found a significant relationship between relational dimension measured by "trust and trustworthiness" and "resource exchange and combination". Norm of reciprocity was not a significant indicator of knowledge sharing in Wasko \& Faraj (2005). Chiu, et al. (2006) found that social interaction ties, reciprocity and indentification although related to the quantity of knowledge shared, did not relate to the qualiy of knowledge shared. In this sense their results were quite similar to current study even though conducted in different context. Bolino (2002) argued that strong ties amongst the individuals lead them to identify with each other. Tsai \& Ghoshal (1998) showed that social interaction ties are significantly related to trust and trustworthiness which in turn is related to resource exchange and combination. It could be argued on the basis of these studies that these dimensions could have an indirect relationship with knowledge sharing. Cognitive dimension of social capital was found to have significant relationship with knowledge sharing. This is in line with the findings of Wasko \& Faraj (2005) and Chiu, et al. (2006). A somewhat counterintuitive finding was that the relationship between knowledge sharing and academic performance was found to be negative. It is difficult to explain these results. One possible explanation could be the use of relative (norm-referenced) grading technique. This sort of grading evaluates the students with reference to the classmates and hence provides incentive to withhold knowledge. This could be because the knowledge is perceived to be related to better grades, hence the incentive for withholding knowledge at least from ones' 
classmates. Many researchers have identified this drawback in relative grading system. Rose (2011) argued that relative grading contributes to the competitive environment of the class. Kohn (1999) also argued that this sort of grading system negatively affects the student relationships. Hence relative grading method could be regarded as a possible hindrance towards knowledge sharing.

In summary current study leads to the conclusion that not all the dimensions of social capital are significantly related to knowledge sharing by the students. This is however not an unusual finding. Nahapiet \& Ghoshal (1998) argued that all dimensions of social capital do not reinforce each. Other empirical studies have also corroborated their point of view (e.g. Chiu, et al., 2006; Tsai \& Ghoshal, 1998; Wasko \& Faraj, 2005). Similarly acadmic performance was found not be a function of knowledge sharing. This is a finding that university administrations need to look into. Knowledge sharing environment in a university can lead to a greater breadth and depth of knowledge since the students can rely on each other in terms of additional materials in addition to the regular mandatory materials. Hence university administrations need to provide forums for knowledge sharing such as increased team work and discussion rooms etc.

Possible limitations of the study include its convinience sampling technique that could limit the generalizability. Secondly it only judges one antecedent of knowledge sharing in isolation, there could other factors that could affect knowledge sharing by students. Future studies in the area could provide a deeper insight into student behaviors in terms of knowledge sharing by employing different research designs such as experimentation and different data collection techniques such as focus groups. Another factor that needs to be explored further is whether the use of technology (e.g. online discussion forums) does enhance the propensity to share (useful) knowledge by the students.

\section{References}

Adler, P. S. (2001). Market, hierarchy, and trust: the knowledge economy and the future of capitalism. Organization Science, 12(2), 215-234.

Adler, P. S., \& Kwon, S. W. (2002). Social capital: Prospects for a new concept. Academy of Management Review, 27(1), 17-40.

Bock, G. W., Zmud, R. W., Kim, Y. G., \& Lee, J. N. (2005). Behavioral intention formation in knowledge sharing: Examining the roles of extrinsic motivators, social-psychological forces, and organizational climate. MIS Quarterly, 29(1), 87-111.

Boix, C., \& Posner, D. N. (1996). Making Social Capital Work: A Review of Robert Putnam's Making Democracy Work: Civic Traditions in Modern Italy. Harvard University Centre for International Affairs Working Paper Series, 96-94.

Bolino, M. C., Turnley, W. H., \& Bloodgood, J. M. (2002). Citizenship behavior and the creation of social capital in organizations. Academy of Management Review, 27(4), 505-522.

Burt, R. S. (1997). The contingent value of social capital. Administrative Science Quarterly, 42(2), 339-365.

Chiu, C. M., Hsu, M. H., \& Wang, E. T. G. (2006). Understanding knowledge sharing in virtual communities: An integration of social capital and social cognitive theories. Decision Support Systems, 42(3), 1872-1888.

Chow, W. S., \& Chan, L. S. (2008). Social network, social trust and shared goals in organizational knowledge sharing. Information \& Management, 45(7), 458-465. 
Chua, A. (2002). The influence of social interaction on knowledge creation. Journal of Intellectual Capital, 3(4), 375-392.

Coleman, J. S. (1988). Social capital in the creation of human capital. American Journal of Sociology, 94(1988), S95-S120.

Cronbach, L. J. (1951). Coefficient alpha and the internal structure of tests. Psychometrika, 16(3), 297-334.

Das, A., Paul, H., \& Swierczek, F. W. (2008). Developing and validating total quality management (TQM) constructs in the context of Thailand's manufacturing industry. Benchmarking: An International Journal, 15(1), 52-72.

Davenport, T. H. (1997). Ten principles of knowledge management and four case studies. Knowledge and Process Management, 4(3), 187-208.

Evans, P. (1996). Government action, social capital and development: reviewing the evidence on synergy. World Development, 24(6), 1119-1132.

Fernandez, R. M., Castilla, E. J., \& Moore, P. (2000). Social capital at work: Networks and employment at a phone center. American Journal of Sociology, 105(5), 1288-1356.

Forza, C., \& Filippini, R. (1998). TQM impact on quality conformance and customer satisfaction: a causal model. International Journal Of Production Economics, 55(1), 120.

Hair Jr, J. F., Anderson, R. E., Tatham, R. L., \& Black, W. C. (2007). Multivariate Data Analysis: With Readings (6th ed.): Prentice-Hall, Inc.

Hansen, M. T. (1999). The search-transfer problem: The role of weak ties in sharing knowledge across organization subunits. Administrative Science Quarterly, 44(1), 82-111.

Hansen, M. T. (2002). Knowledge networks: Explaining effective knowledge sharing in multiunit companies. Organization Science, 13(3), 232-248.

Hyden, G. (1997). Civil society, social capital, and development: Dissection of a complex discourse. Studies in Comparative International Development (SCID), 32(1), 3-30.

Jones, T., \& Taylor, S. F. (2012). Service loyalty: accounting for social capital. Journal of Services Marketing, 26(1), 60-75.

Kohn, A. (1999). From degrading to de-grading. High School Magazine, 6(5), 38-43.

Krause, D. R., Handfield, R. B., \& Tyler, B. B. (2007). The relationships between supplier development, commitment, social capital accumulation and performance improvement. Journal of Operations Management, 25(2), 528-545.

Lang, J. C. (2004). Social context and social capital as enablers of knowledge integration. Journal of Knowledge Management, 8(3), 89-105.

Levin, D. Z., \& Cross, R. (2004). The strength of weak ties you can trust: The mediating role of trust in effective knowledge transfer. Management Science, 50(11), 1477-1490.

Lin, N. (1999). Social networks and status attainment. Annual Review of Sociology, 25(1), 467487.

McCallum, S., \& O'Connell, D. (2009). Social capital and leadership development: building stronger leadership through enhanced relational skills. Leadership \& Organization Development Journal, 30(2), 152-166.

Monnavarian, A., \& Amini, A. (2009). Do interactions within networks lead to knowledge management? Business Strategy Series, 10(3), 139-155.

Mu, J., Peng, G., \& Love, E. (2008). Interfirm networks, social capital, and knowledge flow. Journal of Knowledge Management, 12(4), 86-100. 
Nahapiet, J., \& Ghoshal, S. (1998). Social capital, intellectual capital, and the organizational advantage. Academy of Management Review, 23(2), 242-266.

Nelson, K. M., \& Cooprider, J. G. (1996). The contribution of shared knowledge to IS group performance. MIS Quarterly, 20(4), 409-432.

Nonaka, I. (1994). A dynamic theory of organizational knowledge creation. Organization Science, 5(1), 14-37.

Portes, A., \& Sensenbrenner, J. (1993). Embeddedness and immigration: Notes on the social determinants of economic action. American Journal of Sociology, 98(6), 1320-1350.

Rhodes, J., Lok, P., Hung, R. Y. Y., \& Fang, S. C. (2008). An integrative model of organizational learning and social capital on effective knowledge transfer and perceived organizational performance. Journal of Workplace Learning, 20(4), 245-258.

Rose, L. (2011). Norm-Referenced Grading in the Age of Carnegie: Why Criteria-Referenced Grading Is More Consistent with Current Trends in Legal Education and How Legal Writing Can Lead the Way. Journal of Legal Writing Institute, 17, 123.

Rosenthal, E. (1997). Social networks and team performance. Team Performance Management, 3(4), 288-294.

Savage, D. A., \& Torgler, B. (2010). The relationship between Stress, Strain and Social Capital. Working Papers.

Tabachnick, B. G., Fidell, L. S., \& Osterlind, S. J. (2007). Using Multivariate Statistics (5th ed.): Allyn and Bacon Boston.

Teng, J. T. C., \& Song, S. (2011). An exploratory examination of knowledge-sharing behaviors: solicited and voluntary. Journal of Knowledge Management, 15(1), 104-117.

Tohidinia, Z., \& Mosakhani, M. (2010). Knowledge sharing behaviour and its predictors. Industrial Management \& Data Systems, 110(4), 611-631.

Tsai, W., \& Ghoshal, S. (1998). Social capital and value creation: The role of intrafirm networks. Academy of Management Journal, 41(4), 464-476.

Tymon, W. G., \& Stumpf, S. A. (2003). Social capital in the success of knowledge workers. Career Development International, 8(1), 12-20.

Wasko, M. M. L., \& Faraj, S. (2005). Why should I share? Examining social capital and knowledge contribution in electronic networks of practice. MIS quarterly, 29(1), 35-57.

Weber, B., \& Weber, C. (2007). Corporate venture capital as a means of radical innovation: Relational fit, social capital, and knowledge transfer. Journal of Engineering and Technology Management, 24(1), 11-35.

Widén-Wulff, G., \& Ginman, M. (2004). Explaining knowledge sharing in organizations through the dimensions of social capital. Journal of Information Science, 30(5), 448-458.

Woolcock, M. (1998). Social capital and economic development: Toward a theoretical synthesis and policy framework. Theory and Society, 27(2), 151-208.

Yang, J., Alejandro, T. G. B., \& Boles, J. S. (2011). The role of social capital and knowledge transfer in selling center performance. Journal of Business \& Industrial Marketing, 26(3), 152-161.

Yli-Renko, H., Autio, E., \& Sapienza, H. J. (2001). Social capital, knowledge acquisition, and knowledge exploitation in young technology-based firms. Strategic Management Journal, 22(6-7), 587-613. 